NASZA DERMATOLOGIA Online OUR DERMATOLOGY Online

Source of Support: Nil

Competing Interests: None

\section{CUTANEOUS MANIFESTATIONS OF DERMATOMYOSITIS IN MALE PATIENT: A RARE REPORT}

\author{
Ganesh Dhavalshankh ${ }^{1}$, Archana Dhavalshankh², \\ Vaishali Masvekar ${ }^{1}$
}

${ }^{1}$ Department of Skin and V.D, R.C.S.M. Medical College, Kolhapur, India

${ }^{2}$ Department of Pharmacology, D.Y. Patil Medical College, Kolhapur, India

Corresponding author: Ass. Prof. Ganesh Dhavalshankh

archana9595@yahoo.com

\begin{abstract}
Introduction: Dermatomyositis is an idiopathic inflammatory myopathy. It is a systemic disorder that most frequently affects the skin and muscles, but may also affect the joints, the esophagus, the lungs, and, less commonly, the heart.

Case report: It is presented with characteristic cutaneous findings like skin rash as well as progressive symmetrical proximal muscle weakness. Its prevalence rate is approximately one per 100,000 in the general population with a female to male predominance of about 2:1.

Conclusion: We report a male patient with the classical features of dermatomyositis in whom cutaneous changes preceded muscle weakness.
\end{abstract}

Key words: dermatomyositis; Gottron's sign; helitrop sign; poikiloderma; shawl sign

\section{Introduction}

Dermatomyositis is an idiopathic inflammatory myopathy (IIM) $[1,2]$. It is a systemic disorder that most frequently affects the skin and muscles, but may also affect the joints, the esophagus, the lungs, and, less commonly, the heart $[3,4]$. It is presented with characteristic cutaneous findings like skin rash as well as progressive symmetrical proximal muscle weakness. It has extramuscular manifestations such as joint contractures, dysphagia, cardiac disturbance, pulmonary symptoms, and subcutaneous calcifications. DM also has an association with malignant disease, and various autoimmune and connective tissue diseases. The average age at diagnosis is $40 \mathrm{yr}$, and almost twice as many women are affected as men [3,4]. It's prevalence rate is approximately one per 100,000 in the general population with a female to male predominance of about $2: 1$. DM is usually associated with an underlying malignancy, and its prevalence is even rarer without coexistent cancer $[5,6]$. Dermatomyositis is a connective tissue disorder constituting inflammatory myopathy along with characteristic cutaneous markers. The diagnostic criterias for the disease has been defined [7]. The various cutaneous manifestations in dermatomyositis, may precede or follow myositis $[8,9]$. However dermatomyositis can present without muscle weakness [10].

\section{Objectives}

We report a male with the classical features of dermatomyositis in whom cutaneous changes preceded muscle weakness. The presenting cutaneous lesions in dermatomyositis include a heliotrope rash with edema, photosensitivity, Gottron's papules and poikiloderma.

\section{Case Report}

A 32 years male patient with previous healthy condition presented to us 2 months back with red colored rash \& swelling around both eyes and cheeks. He noticed similar type of rash on both hands, both thighs and both shoulders extending up to mid back. He also complained of severe muscle weakness \& pain in both shoulder joints .He noticed difficulty in combing his hair and aggravation of rash when exposed to sun. The initial maculopapular erythematous rash started on dorsal aspect of both hands and then spread to involve face, back and abdomen since 6 months. Since last two months he noticed difficulty in climbing stairs, getting up from squatting position and combing his hair. The muscle weakness was bilateral and gradually progressive without any fasciculations. The clinical examination revealed bilateral periorbital erythematous rash and edema covered with fine white scales suggestive of heliotrope rash (Fig. 1) which is highly suggestive of dermatomyositis. 
Similartype ofrash wasalso presenton bothmalar prominences, dorsii of both hands, abdomen and $\mathrm{V}$ of neck mostly covering sun-exposed areas suggestive of poikiloderma (Fig. 2). The rash extended on upper part of the back suggestive of shawl sign (Fig. 3). There were hyperpigmentation papules found on bony prominences particularly the metacarpophalangeal and iterphalangeal joints suggestive of Gottron papules and Gottron's sign (Fig. 4).

The systemic examination revealed mild pallor. There was weakness of various group of muscles up to grade II. None of the muscles were atrophic but tenderness was present in the muscles of extremities. No fasciculations were seen in any of the muscles. Deep tendon, abdominal and plantar reflexes were normal. The breasts, genitalia and gastrointestinal tract were normal. No periinguinal erythema and nailfold telangiectasia or cuticular dystrophy observed. No mechanics hand lesions (fissured scaly hyperkeratosis) were found. Laboratory data revealed haemoglobin $13.88 \mathrm{gm} / \mathrm{dl}$, total leukocyte count $5900 / \mathrm{mm}^{3}$, P73L19M4E4B0, platelets $1.9 \mathrm{lacs} / \mathrm{mm}^{3}$ and ESR $16 \mathrm{~mm} / \mathrm{hr}$. Urine analysis, blood glucose, blood urea, serum creatinine and serum uric acid were within normal limits. LE cells and antinuclear factors (by indirect immunoflourescence) were not detected (0.66) and anti-dsDNA was negative (19.13

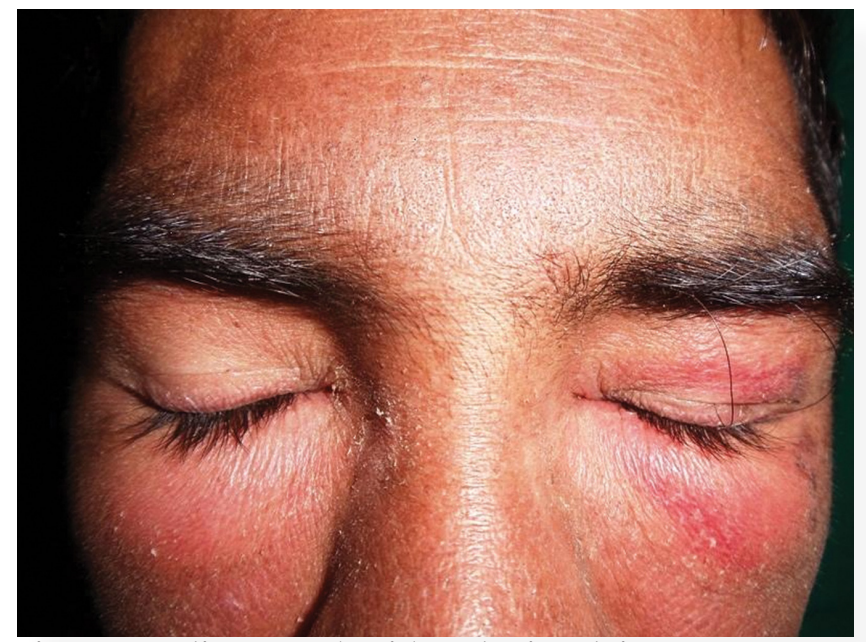

Figure 1. Helitrope rash with scales involving periorbital skin

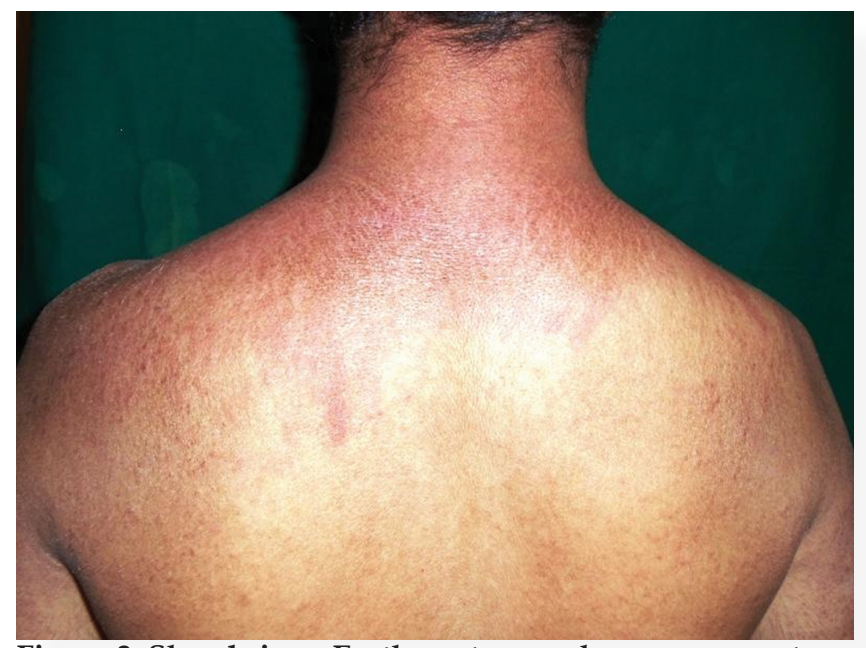

Figure 3. Shawl sign - Erythematous rash on upper part of back
IU/ml). CPK was 195 units/dl ( $\mathrm{n}=10-70)$, CPK (MB) 36.78 units/dl ( $\mathrm{n}<5$ percent of total), LDH 299 units/dl ( $\mathrm{n}=200-450)$ and SGOT was 23 units/ml $(\mathrm{n}=15-45)$. RA test was negative. Ultrasonography of abdomen including pelvis, and ECG were normal. A skin biopsy showed mild hyperkeratosis, patchy parakeratosis, spongiosis, focal thinning, hydropic degeneration of basal cell layer with lymphocytic exocytosis. The upper dermis showed band-like lymphocytic infiltrate, incontinence of pigment and dilated capillaries (Fig. 5).

The patient received $10 \mathrm{mg}$ of oral prednisolone twice daily along with $200 \mathrm{mg}$ of hydroxychloroquine twice a day and once weekly $10 \mathrm{mg}$ of methotrexate. The therapy was supplemented with oral antioxidants, folic acid and topical diluted mometasone furoate at night and broad spectrum sunscreen during daytime. The muscle weakness was gradually improved over a period of four weeks and the muscle enzymes also reduced. The prednisolone was then gradually tapered to $5 \mathrm{mg}$ over a span of four weeks. Presently he is off the steroids and is being maintained on $5 \mathrm{mg}$ of methotrexate once a week and same dose of hydroxychloroquine. The patient has regained his muscle power and there is a drastic improvement in his rash.

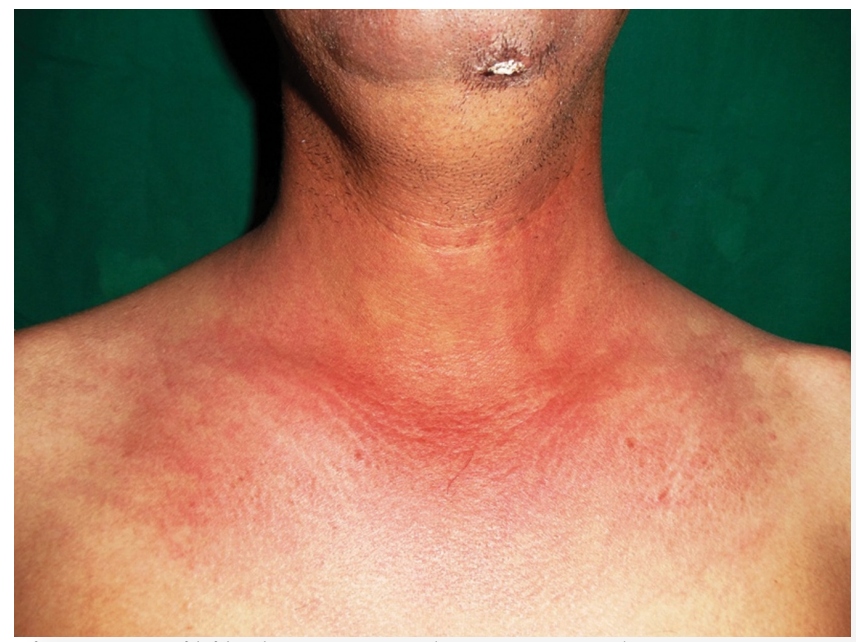

Figure 2. Poikiloderma - Erythematous rash on sun exposed area

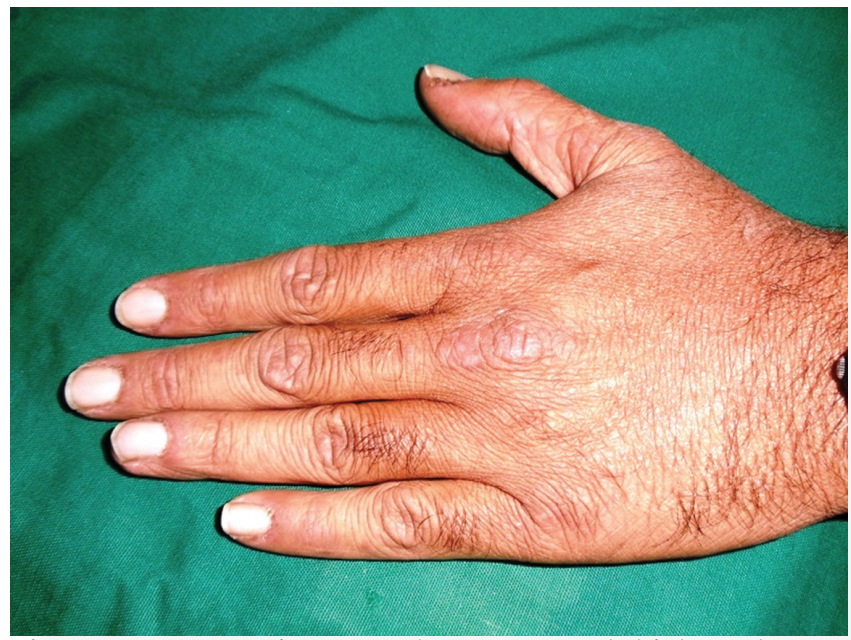

Figure 4. Gottron sign - Erythematous and thickened skin at joints 


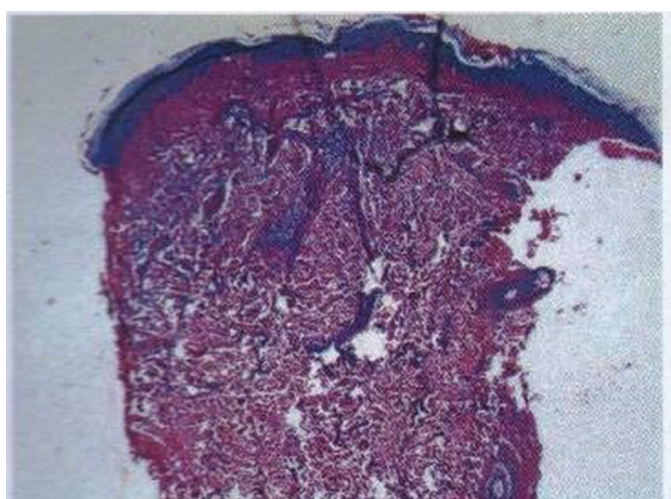

Figure 5. Histopatological changes

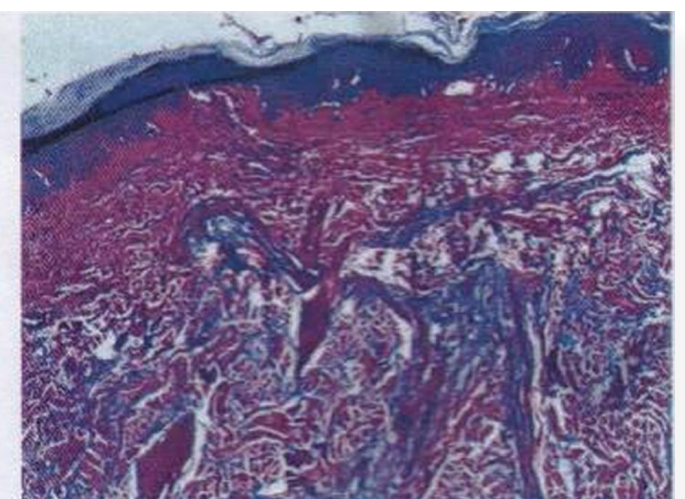

relevant in this case. Though etiology of the disease is unknown, it is believed to be initiated by viral infection and altered immune response. Lymphocyte mediated muscle cell damage and small vessel damage are important central pathogenetic factors. Usually vascular deposits of immune complexes and complement are associated with endothelial cell injury and small vessel obstruction. Dermatomyositis is usually associated with CD4 T cells and B cells infiltrating the muscles whereas polymyositis is associated with CD8 cytotoxic $\mathrm{T}$ cells. This case shows similar biopsy changes like lymphocytic infiltrate, incontinence of pigment and dilated capillaries.

\section{REFERENCES}

1. Suber TL, Casciola-Rosen L, Rosen A: Mechanisms of disease: autoantigens as clues to the pathogenesis of myositis. Nat Clin Pract Rheumatol. 2008,4:201-9.

2. Dalakas MC, Hohlfeld R: Polymyositis and dermatomyositis. Lancet. 2003,362:971.

3. Scheinfeld NS: Ulcerative paraneoplastic dermatomyositis secondary to metastatic breast cancer. Skinmed. 2006;5:94-6.

4. Drake LA, Dinehart SM, Farmer ER, Goltz RW, Graham GF, Hordinsky MK, et al: Guidelines of care for dermatomyositis. J Am Acad Dermatol. 1996;34:824-9.

5. Bohan A, Peter JB, Bowman RL, Pearson CM: Computer-assisted analysis of 153 patients with polymyositis and dermatomyositis. Medicine (Baltimore). 1977;56:255.

6. Sigurgeirsson B, Lindelof B, Edhag O, Allander E: Risk of cancer in patients with dermatomyositis or polymyositis. N Engl J Med. 1992;326:363.

7. Bohan A, Peter JB: Polymyositis and dermatomyositis. N Eng J Med. 1975;292:403-7.

8. Rockerbie NR, Woo TY, Callen JP, Giustina T: Cutaneous changes of dermatomyositis precede muscle weakness. J Am Acad Dermatol. 1989;20:629-32.

9. Tymms K, Webb J: Dermatopolymyositis and other connective tissue diseases: a review of 105 cases. J Rheumatol. 1985;12:11408.

10. Cosnes A, Amaudric F, Gherardi R, Verroust J, Wechsler J, Revuz J, et al: Dermatomyositis without muscle weakness. Arch Dermatol. 1995;131:1381-5.

11. Shirani Z, Kucenic MJ, Carroll CL, Fleischer AB Jr, Feldman SR, Yosipovitch G, et al: Pruritus in adult dermatomyositis. Clin Exp Dermatol. 2004;29:273-6.

12. Dalakas MC: Current treatment of the inflammatory myopathies. Curr Opin Rheumatol. 1994;6:595-601. 
13. Mastaglia FL, Ojeda VJ: Inflammatory myopathies: Part 2. Ann Neurol. 1985; 17:317-23.

14. Mastaglia FL, Ojeda VJ: Inflammatory myopathies: Part 1. Ann Neurol. 1985; 17:215-27.

15. Airio A, Pukkala E, Isomäki H: Elevated cancer incidence in patients with dermatomyositis: a population based study. J Rheumatol. 1995;22:1300-3.

16. Chow WH, Gridley G, Mellemkjaer L, McLaughlin JK, Olsen JH, Fraumeni JF Jr: Cancer risk following polymyositis and dermatomyositis: a nationwide cohort study in Denmark. Cancer Causes Control. 1995;6:9-13.
17. Hill CL, Zhang Y, Sigurgeirsson B, Pukkala E, Mellemkjaer L, Airio A, et al: Frequency of specific cancer types in dermatomyositis and polymyositis: a population-based study. Lancet. 2001;357:96100 .

18. Antiochos BB, Brown LA, Li Z, Tosteson TD, Wortmann RL, Rigby WF: Malignancy is associated with dermatomyositis but not polymyositis in Northern New England, USA. J Rheumatol. 2009;36:2704-10.

19. Fardet L, Dupuy A, Gain M, Kettaneh A, Chérin P, Bachelez $\mathrm{H}$, et al: Factors associated with underlying malignancy in a retrospective cohort of 121 patients with dermatomyositis. Medicine (Baltimore). 2009;88:91-7. 